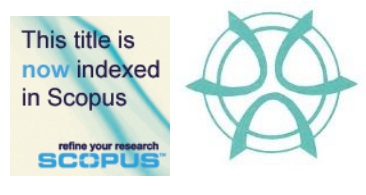

PLANNING MALAYSIA:

Journal of the Malaysian Institute of Planners

VOLUME 15 ISSUE 4 (2017), Page 69 - 78

\title{
CHANGES AND THREATS IN THE PRESERVATION OF THE TRADITIONAL MALAY LANDSCAPE
}

\author{
Nor Zalina Harun ${ }^{1}$, Noor Aziah Mohd Ariffin², \& Fadzidah Abdullah ${ }^{3}$ \\ ${ }^{1}$ Institute of Malay World and Civilization \\ UNIVERSITI KEBANGSAAN MALAYSIA \\ ${ }^{2,3}$ Kulliyyah of Architecture and Environmental Design \\ INTERNATIONAL ISLAMIC UNIVERSITY MALAYSIA
}

\begin{abstract}
The cultural landscape is regarded as being of the most complex designs which involves interactions between man, nature, cultural values and the associated built environment. Issues relating to the degradation of the cultural landscape are often caused by rapid urbanisation and industrialisation. The traditional Malay Landscape exists through harmoniously balanced interactions between man, nature and culture together with the traditional house, and contains unique and interesting features that have to be preserved as one of the most important cultural heritage sites. However, the preservation of heritage in Malaysia tends to focus more on architectural buildings rather than adopting a holistic approach that includes the surrounding environment of where the building is located. The absence of such approach has contributed towards the loss of the traditional Malay Landscape. This study highlights the changes and threats in the preservation of the traditional Malay Landscape by focusing on the preservation of a traditional house compound. The research employs a qualitative approach which involves site visits, interviews, and document analysis concerning the research topic. The old Malay villages located in Tumpat, Kelantan and Alor Gajah, Melaka have been selected as case studies. The findings reveal that the changes and threats include four underlying aspects; Unsuitable and inappropriate uses, Ownership Problems, Inadequate fund and consultation and Current development trends. The study concludes that the traditional Malay Landscape is facing numerous changes and threats in terms of its physical characteristics, environmental aspects and cultural values. In addition, the study reveals that traditional Malay landscape is not seen here as an integrating, holistic concept.
\end{abstract}

Keywords: Traditional Malay landscape; changes; threats; heritage; preservation

Date Received: $18^{\text {th }}$ July 2017

Date of Acceptance: $8^{\text {th }}$ November 2017 
Nor Zalina Harun, Noor Aziah Mohd Ariffin, \& Fadzidah Abdullah

Changes and Threats in The Preservation of the Traditional Malay Landscape

\section{INTRODUCTION}

Conservation is known as a process of looking after or managing changes. It also includes maintenance and may, according to circumstances, include preservation, restoration, reconstruction and adoption and often a combination of more than one of these philosophies. According to International Council on Monuments and Site or ICOMOS (2007), conservation is a process which leads to the prolongation of life of cultural property and for its utilization now and in the future, it is also to recapture a sense of the past and to conserve, as much as possible the existing fabric in its original condition or situation. It is also a process that seeks to promote the harmony of both private and community lives in the affected areas (Kottak, 1994; Samsudin, 2013). In addition, it is also referring to the encouragement of the preservation of those cultural properties that constitutes the memory of mankind.

The global society has started to recognise the importance of conservation in early $20^{\text {th }}$ century. Simultaneously, conservation works began to receive positive reaction by all quarters of expert, especially in the field of historic building. In Malaysia, conservation initiatives only began to capture government attention during the 1970's. This culminated in the Antiquity Act (Act 168) in 1976, and most recently, the National Heritage Act (2005).

It is evident that the preservation of heritage in Malaysia tends to focus more on architectural buildings rather than adopting a holistic approach that includes the surrounding environment of where the building is located (Abdul Razak, 2015; Aidatul, Nooridayu \& Norajlin, 2012). As a result, the absence of such approach has contributed towards the loss of the traditional or cultural landscape.

This paper aims to explore the current condition and challenges in achieving the holistic preservation effort by focusing on the Malay Landscape. The first objective is to identify the special attributes and components that form the Malaysian landscape. The second objective is to identify the various changes and threats concerning the preservation of the traditional Malay Landscape. The third objective is to study the method of protecting the heritage of the traditional Malay Landscape. The research employs a qualitative approach which involves site visits, interviews, and document analysis concerning the research topic. The old Malay villages located in Tumpat, Kelantan and Alor Gajah, Melaka have been selected as the case studies.

\section{THE MALAY LANDSCAPE}

The Malays are well known for having the richness of culture, heritage and inherited values. These personas are shaped from the custom of the Malays in their daily activities. Zakaria, Salleh \& Sabrizaa (2014a) state that the standard of living of the Malays is much determined by the cultural and customary practices. This was translated into the development in the Malaysian landscape starting from the early days of the Malacca Sultanate in the 14th century and the 15th. Based 
on the record of Abdullah Munsyi in his book "The Travels of Abdullah", the forbidden garden on the Malacca Sultanate era is the earliest garden in Malaysia (Osman \& Yusoff, 1983). Munshi also described the beauty of a flower garden of the Kelantan sultanate in the 16th century called as the Tanah Serendah Sekebun Bangui. Moreover, it was also narrated of the Hunting Park and Central Melaka sultanate known as Ghairat Park and Kraton Park (Samsudin, 2014). In the traditional Malay garden, the house compound is divided into three different spaces based on functions. The plants and the components of the compound associate with the space itself. The composition of the Malay garden consists of the front compound, side compound and rear compound (Figure 1). The spaces create the identity of Malay garden and were derived from their culture, belief and religion.

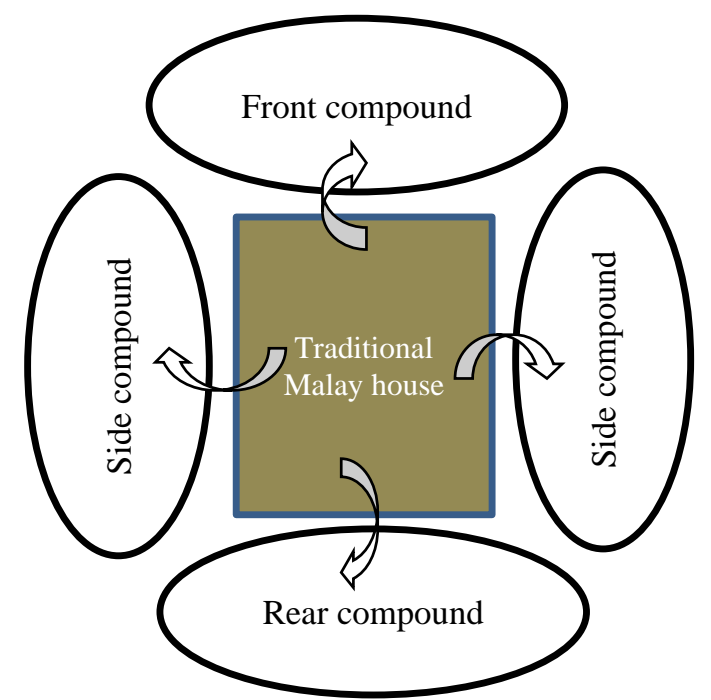

Figure 1 The spatial composition of the traditional Malay garden

\section{Front Compound}

The front compound (laman hadapan), or the open lawn, is situated in front of the house facing the main road. It is the wide space cleared of any obstruction giving ample space to conduct communal activity when required, such as wedding ceremony, feast, and space for children playing. Ismail, Utaberta and Ismail (2015) state that the open lawn being a main space that connect the front compound and side compound of the garden. In the eastern region of Peninsular Malaysia, this area is being used for drying fish, paddy winding as well as for drying clothes. The plants planted in front compound are usually ornamental, fragrant, colourful and small in size. This is to welcome the guests as well as to accentuate the appearance of the house (Zakaria, Salleh \& Sabrizaa, 2012a). 
Nor Zalina Harun, Noor Aziah Mohd Ariffin, \& Fadzidah Abdullah

Changes and Threats in The Preservation of the Traditional Malay Landscape

\section{Side Compound}

The side compounds (laman sisi) are located on the right and left side of traditional Malay house. This space links with the front compound and rear compound. This compound is slightly narrow and elongated to the rear yard. The second entrance is located in this compound to link a house garden with the neighbour's house compound. Moreover, this compound is a multipurpose area to accommodate the daily activities such as space for relaxing, leisure, gathering space for the family, and at the same time to entertain their neighbour and relatives. Hence, it helps to strengthen the relationship among the village society. Trees, such as fruit trees, are planted in this area and being the source of food. Hardscape elements like shelters, paddy store and hen coop are among many important elements that increase the functionality of the space (Zakaria, Salleh \& Sabrizaa, 2012b).

\section{Rear Compound}

The rear compound (laman belakang) is related to the kitchen activities such as cooking, bathing and washing as well as for orchard and farming. It is usually unturfed as the compound normally used for cooking, feeding the livestock and storage of kitchen utensils. This space is usually dominated by the women as they spend more time in the kitchen. This space also creates the sense of privacy due to the planting composition, whereby the trees and shrubs are planted close to one another. Trees with canopy are planted to make the backyard area as an isolated zone. Also, back yard has a high density of plants and scattered layout as its function to absorb the unpleasant smell from the remaining pool or water channel called as parit and the livestock. This space is considered as kitchen garden or edible garden as it provided the domestic raw food, fruit trees and herbs as medicinal purpose (Zakaria, Salleh \& Sabrizaa, 2014b; Ismail, Utaberta \& Ismail 2015).

\section{Hardscape Element}

The application of hardscape elements in the traditional Malay garden is to support the daily activities of the residents, their relatives, and guests and village community. As plants are planted according to the suitable use of the space, the landscape furniture are also placed according to the use of the element and the function of the area (Nasir \& Wan Teh, 1997). The location of the house, either in the coastal, mainland or rural area, also affects the types of hardscape elements applied (Shuaib \& Enoch, 2013). Moreover, the placement of hard landscape element is a manifestation of the house owner status in social, culture and religious belief. Zakaria, Salleh and Sabrizaa (2012b) and (2013), suggest that a Malay landscape garden is a place for the community to develop their social bonding. Table 1 lists the common hard landscape elements in Traditional Malay house compound. 
PLANNING MALAYSIA

Journal of the Malaysia Institute of Planners (2017)

Table 1 Hardscape elements in the Traditional Malay house compound.

\begin{tabular}{lll}
\hline Local name & Common Name & Placement area \\
\hline Ampaian & Clothes line & \\
Guri & Guri & \\
Kolah & Water tank & Front compound \\
Pasu Bunga & Flower pot & \\
Titi & Log bridge & \\
Wakaf & Gazebo & \\
\hline Perigi & Well & Rear compound \\
Bangsal & Barn & \\
Kolam & Pond & \\
Pelantar & Open timber platform & Side compound \\
Tandas & Latrine & \\
\hline Kepokpadi & Paddy store & \\
Pangkin & Resting hut & \\
Reban & Chicken coop & \\
Tempayan & Water vessel & \\
\hline
\end{tabular}

\section{Softscape Elements}

Softscape elements in traditional Malay house compound represent the nature related to their colloquial activities. It consists of varying types and species of plants. Softscape elements are usually used for ornamental and medicinal purposes. They also provide fresh ingredients for cooking as well as create shade. The type of plants may include climbing plants, orchid plants and exotic plants. Shrubs and ground cover are often planted in the front compound as ornamental, which can give benefits in terms of their shape, colour, smell, and size. In the rear compound is the kitchen garden where herbs and vegetables are planted for use in cooking. Meanwhile, shady trees like beringin and ketapang are planted in the side compound to provide shade. Fruit trees such as rambutan, mango, mangosteen and durian tree are also sometimes planted in the compound of Malay traditional house.

\section{METHODOLOGY}

This study employed qualitative research method. Primary data were obtained through site visits, observation and interview. Meanwhile, secondary data were gathered through literature review of Malay culture and traditional Malay garden. Interviews with the house owners and tenants have revealed information regarding the changes or adverse effects on which the hardscape and softscape elements in the ten selected traditional Malay houses were affected or changed.

Sites in Kelantan and Melaka were selected as case studies as both states have rich elements of culture and plenty of traditional Malay villages that are still 
Nor Zalina Harun, Noor Aziah Mohd Ariffin, \& Fadzidah Abdullah

Changes and Threats in The Preservation of the Traditional Malay Landscape

being preserved today. The preservation of the traditional Malay houses in Melaka is monitored by Perbadanan Muzium Melaka (PERZIM). According to PERZIM, more than 100 traditional Malay houses in villages in Melaka have been earmarked for preservation. Meanwhile, Shuaib and Enoch (2013) believe that the traditional Malay house in Kelantan has the most traditional aesthetic values. The selected site in Kelantan is Kampung Chenderong Batu located in the district of Wakaf Bharu and Tumpat, while in Melaka the sites are located in Kampung Padang Sebang, Kampung Tanjung Rimau Luar and Kampung Gadek, in the district of Alor Gajah.

In overall, ten traditional Malay houses were selected from the study areas. All of the houses were owner-occupied, except two in Alor Gajah, which were rented to local tenants. The houses displayed minimal deterioration. The houses' compounds contained special structures of hardscape and softscape belonging to various historical periods (more than 100 years), which are worthy of preservation.

The very contextual and scope of the study will inevitably influence and limit the generality of the study findings. Besides the above, the major limitations of the study were that the study areas being limited to the locality of the historic buildings within two states. Thus findings may be of slight relevance and applicability to other part in the country. Finally, the study also assumed that the respondents interviewed have some level of knowledge in traditional Malay landscape and the need for their preservation.

\section{FINDINGS}

The study shows that the front compound of most of the houses in Kelantan and Melaka still maintain the composition of open free space often found in the front area of a traditional Malay house. Similarly, most of the houses also maintain the traditional combination of plants such as herbs, fragrance, fruit trees and brightly coloured flowering plants. For houses in Kelantan, the side and rear compound were planted with plants that are associated with food and daily necessities for the use in cosmetics and medicine. These imply that the plants were planted to create an aesthetic sense, provide habitat for wildlife as well as to provide shade and shelter. Thus, it can be said that traditional Malay landscape actually creates a balance ecological system. In addition, the use of various shapes and characters of the plants resulted in pleasant and soothing environment. In terms of cultural aspect, the landscape was created for social interaction among the community members suggesting a strong mutual relationship and understanding.

Nevertheless, several issues were identified that have contributed to the deterioration of the landscape of the traditional Malay houses. These are presented below. 
PLANNING MALAYSIA

Journal of the Malaysia Institute of Planners (2017)

\section{Use of Unsuitable Material}

From observation, some of the compounds were cleared of the natural turfing and resurfaced with premix and other types of hard surfaces. This has changed the original setting of the compound. In some cases, softscape such as fruit trees and shrubs were removed for easy maintenance of the compounds. But this has led to increase heat during the day.

Some of the houses were inherited by the present owners who may not understand or appreciate the traditional landscape concept and design adopted by the original owner. As a result, present owners have redesigned the compounds according to their liking and, in the process, changed the original traditional setting of the compounds.

\section{Lack of Maintenance}

The problem of lack of maintenance can be attributed to several reasons. Firstly, to most residents of the houses, the maintenance of the houses was much more important than the compounds. Therefore, while the houses were repaired and maintained, the compounds were often not. This resulted in poorly maintained compounds of the houses being studied.

The issue of house ownership also contributed to lack of maintenance of the houses compounds. In the event of death of the original owner, the house, including the compounds, is often left unattended until the ownership of the house is legally transferred to an heir or a new owner. The situation was made worse when no heir or new owner was willing to stay in the house even after ownership has been transferred. This leaves the house and the compounds unattended and decayed.

This study also found that the traditional houses which were rented out also tend to have the problem of lack of compound maintenance. This was because tenants were unwilling to spend or cannot afford the cost of maintaining the compounds. As a result, the maintenance of the compounds was being neglected by the tenants.

\section{Inadequate Fund and Consultation}

Some of the traditional houses were given a one-off financial assistance by the local authorities for their conservation and maintenance work. However, the fund was mainly for works on the house building rather than the compounds. Thus, the amount of fund received was limited and insufficient to include maintenance and conservation works of the compounds.

Besides financial inadequacy, lack of awareness and knowledge of the traditional house owners in terms of the various forms of the art and Malay landscape has also played a role in poor and irregular maintenance of the compounds. As a result, many of these houses and their compounds have been inappropriately altered. 
Nor Zalina Harun, Noor Aziah Mohd Ariffin, \& Fadzidah Abdullah

Changes and Threats in The Preservation of the Traditional Malay Landscape

\section{Current Development Trend}

Modern design of development has influenced owners of traditional houses to also upgrade their residence as well as the traditional landscaping in the house compounds. The compound traditional setting was altered to include contemporary landscape components with modern design and materials. This, if left unchecked, would endangered the conservation of traditional Malay landscape in the country.

\section{CONCLUSION}

The findings from the study reveal that traditional Malay houses in both states, Melaka and Kelantan, appear to share common landscape characteristics. The landscape is generally characterised by the three types of space, which are the front compound, the rear compound, and the side compounds. The compounds, on the other hand, provide space for social interaction between house owners/occupiers with the community.

The study also found that the traditional Malays landscape is under threat due to lack of, and poor, maintenance work. Issues in house ownership, insufficient funds, and lack of knowledge on traditional Malay landscape have been identified among the factors that threaten the conservation of traditional Malay landscape.

\section{ACKNOWLEDGEMENTS}

This research was supported by a Fundamental Research Grant Scheme by Malaysian Ministry of Higher Learning. We also would like to thank our group of students from Landscape Architecture Department of International Islamic University Malaysia for their assistance during the data collection. 
PLANNING MALAYSIA

Journal of the Malaysia Institute of Planners (2017)

\section{REFERENCES}

Abdul Razak, D. (2015, December 24). Save our vanishing kampong. The New Straits Times. Retrieved from https://www.nst.com.my/news/2015/12/118833/save-our-vanishingkampung

Aidatul, F. B., Nooridayu, A. Y., \& Norajlin, J. (2012). Managing heritage assets: Issues, challenges and the future of historic Bukit Jugra, Selangor. Procedia - Social and Behavioral Sciences, 68(2012), 341-352.

ICOMOS. (2007). Heritage at risk: ICOMOS world report 2006/07 on monuments and sites in danger.

Ismail, N. A, Utaberta, N., \& Ismail, S. (2015). A cultural responsive landscape study on Perak Malay garden: An expressional value. Advances in Environmental Biology, 9(5), 485-490.

Kottak, C. P. (1994). Cultural anthropology (4th Edition). New York, Random House.

Osman, M. T., \& Yusoff, W. K. (1983). Kajian Budaya dan Masyarakat di Malaysia. Kuala Lumpur: Dewan Bahasa dan Pustaka.

Samsudin, N. A. (2013). Influence of traditional Malay settlements physical design attribute on social characteristic: Johor, Malaysia. Retrieved from: http://www.academia.edu/5418878/Influence_of_Traditional_Malay_Settle ments_Physical_Design_Attribute_On_Social_Characteristic_Johor_Malay sia

Samsudin, N. A. (2014, August). The Physical Design Attributes of Traditional Malay Kampong in Kampung Tanjung Bunut, Kuala Terengganu. 5th International Graduate Conference on Engineering, Science \& Humanity. August 19-21, 2014, Johor Bahru, Malaysia.

Shuaib, A. A., \& Enoch, O. F. (2013). Integrating the Malay traditional design elements into contemporary design: An approach towards sustainable innovation. Procedia - Social and Behavioral Sciences, 129 (2014), 59-67.

Nasir, A. H., \& Wan Teh, H. (1997). The traditional Malay house. Kuala Lumpur: Institut Terjemahan Negara Malaysia.

Zakaria, A. Z., Salleh, I. H., \& Sabrizaa, M. (2012a). Landscape furniture present in the ancient Malay garden according to old manuscripts and their effects on the formation of Malay garden design concept model in Malaysia. Procedia - Social and Behavioral Sciences, 91 (2013), 28-35.

Zakaria, A. Z., Salleh, I. H., \& Sabrizaa, M. (2012b, December). Plants present in the ancient Malay garden according to old manuscripts and their effects on the formation of a Malay garden design model in Malaysia. The 9th Regional Symposium of the Malay Archipelago, SIMPORA 9:2012. December 11-12, 2012, Seri Iskandar, Perak, Malaysia.

Zakaria, A. Z., Salleh, I. H., \& Sabrizaa, M. (2013). Malay landscape elements as depicted in the old Malay films. Jurnal Pengajian Melayu, 24, 43-55. 
Nor Zalina Harun, Noor Aziah Mohd Ariffin, \& Fadzidah Abdullah

Changes and Threats in The Preservation of the Traditional Malay Landscape

Zakaria, A. Z., Salleh, I. H., \& Sabrizaa. (2014a). The Malay garden design concept opportunity to be developed as the tourism product. Procedia-Social Behavioral Sciences, 153, 298-307.

Zakaria, A. Z., Salleh, I. H., Harun, S. N., \& Sabrizaa, M. (2014b). Preservation characteristics of Malay garden: A catalyst for sustainable cultural landscape in Malaysia. DOI: 10.1007/978-981-287-332-3_28 